Holmes, W. (1962). Biblthca'Nutr. Dieta' 4, 179.

Holmes, W. (ig66). Agric. Prog. 41,6o.

Holmes, W. (1970). Efficiency of Food Production by the Animal Industries. Proceedings of a Symposium on Potential Crop Production in Britain. London: Heinemann.

Holmes, W. \& Jones, J. G. W. (I964). Proc. Nutr. Soc, 23, 88.

Kielanowski, J. (1967). Proc. int. Congr. Anim. Prod, Ix. Edinburgh, 1966 p. 2 I 2.

Leitch, I. \& Godden, W. (1953). Tech. Commun. Commonw. Bur. Anim. Nutr. no. I4.

Lucas, J. W. (1968). Pl. Fds hum. Nutr. I, I3.

Middleton, T. H. (1923). Food Production in War. Oxford: Clarendon Press.

Ministry of Agriculture, Fisheries and Food (1067). Rep. natn. Fd Surv. Comm. 1965.

Ministry of Agriculture, Fisheries and Food (1969). Rep. natn. Fd Surv. Comm. 1967.

Ministry of Health (1969). Rep. publ. Flth med. Subj., Lond. no. rzo.

Morley, F. H. W. (1969). Proceedings Second World Conference on Animal Production p. 23. St. Paul, Minnesota: American Dairy Science Association.

Pirie, N. W. (1969). Proc. Nutr. Soc. 28, 85.

Pohl, F. \& Kornbluth, C. M. (1965). The Space Merchants. London: Penguin Ltd.

Reid, J. T. (1970). In Physiology of Digestion and Metabolism in the Ruminant p. I. [A. T. Phillipson, editor]. Newcastle upon Tyne: Oriel Press.

Rostow, W. W. (1960). The Process of Economic Growth and ed. London: Oxford University Press.

Schuphan, W. (I 965). Nutritional Values in Crops and Plants. London: Faber and Faber.

Spedding, C. R. W. (1969). Agric. Prog. 44, 7.

United Nations Economic and Social Council. (1968). The Protein Problem. Rep. E/4592 of the Secretary General, United Nations.

Virtanen, A. I. (1969). A Finnish Scientist looks at Protein Deficiency. OECD Agric. Rev. 16, 122.

\title{
Domesticated ruminants as sources of human food
}

\section{By K. L. Blaxter, Rowett Research Institute, Bucksburn, Aberdeen AB2 $9 S B$}

Domesticated ruminants account for about half the world's production of meat and virtually the whole of its production of milk. The most recent statistics on world production of carcass meat, milk and eggs are summarized in Table $I$ from

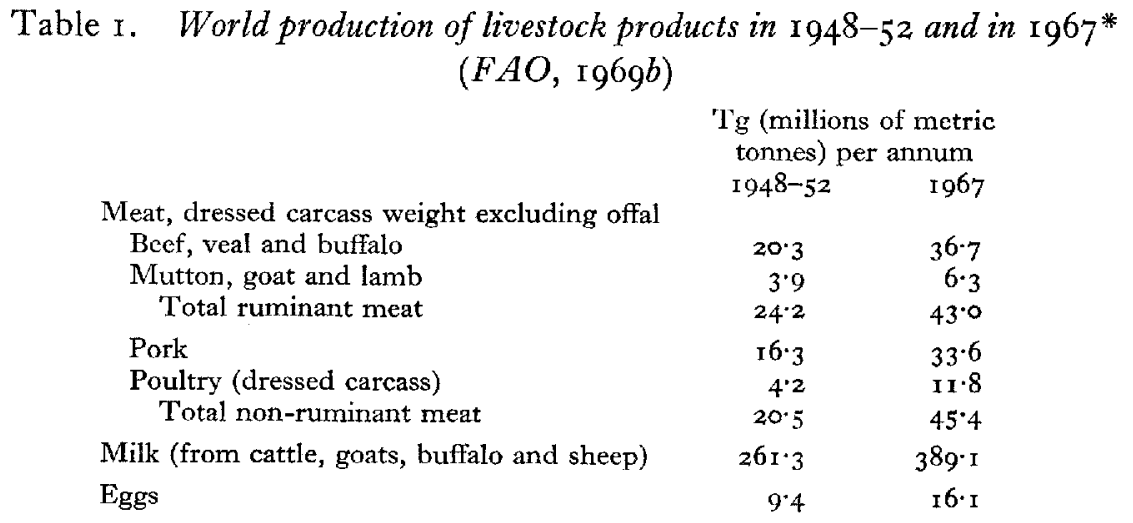

*Estimates had to be made of poultry meat production in mainland China from the stated number of birds, using ratios of number to volume of production in SE Asian countries. The non-ruminant meat is an underestimate since it ignores the considerable production of meat from horses. 
which it can be seen that in the last 17 years meat production from ruminant animals has risen by $78 \%$ and that from non-ruminants by $121 \%$. Milk production in the same period has risen by $49 \%$. The greater rise in meat production from non-ruminants than from ruminants is largely but not entirely accounted for by the phenomenal growth of the world's production of poultry meat.

Statistics such as these are a record of achievement. Since progress towards greater production has been continuous during the i 7 -year period they permit some extrapolation, but any estimates of future productivity so derived are obviously limited. Alternative approaches have necessarily to be adopted, and those chosen to provide estimates of what the future holds are economic ones. The basic premises in the arguments which follow are firstly that the economic wealth of different countries will continue to increase, secondly that increased wealth is associated with increased industrialization, and thirdly that the historical patterns of growth in those countries which are now highly developed will differ relatively slightly from the patterns of growth which will take place in those at present relatively less developed. As an index of industrialization and hence of wealth, the proportion of the population engaged in agriculture has been taken. This is a simple measure uncomplicated by the complexities of accounting which accompany calculation of the gross domestic product and free from difficulties of conversion to a monetary denominator common to all countries.

It has been emphasized by many that people buy more high-quality foods and particularly more animal products as levels of personal income increase (Byerly, 1966; Phillips, 1969; Millikan, 1967). Fig. I, calculated from the most recent FAO (I 969 a) statistics, illustrates this point. For European countries, the USA and Canada, and Middle Eastern countries bordering the Mediterranean, the daily amount of protein provided to each person by meat and milk declines as the proportion of the population engaged in agriculture increases. The between-country regression is highly significant statistically, and indicates that in the most highlydeveloped countries with about $5 \%$ of their population engaged in agriculture, meat and milk together provide $52.5 \mathrm{~g}$ protein/person per $\mathrm{d}$ and for every $10 \%$ increase in the agricultural population protein intake declines by $6.3 \mathrm{~g}$ protein/ person per $\mathrm{d}$. These figures apply to Western societies, or those which are probably aspiring to Western standards. They do not apply to individual primary-producing countries or to Asian or Far Eastern countries though, in general, for large divisions they certainly apply as shown in Table 2 which has been calculated from FAO data (UNO, I968).

Table 2. Proportion of dietary calories represented by animal protein in relation to per capita gross domestic product (UNO, 1968)

Asia and Far East

Africa

Near East

Per capita gross product $(\$)$

Latin Atnerica

Developed countries

\begin{tabular}{|c|c|}
\hline 84 & $\mathrm{r} \cdot 4$ \\
\hline 97 & $x \cdot 8$ \\
\hline$x_{59}$ & $2 \cdot 6$ \\
\hline 299 & $3 \cdot 7$ \\
\hline 1368 & $6 \cdot 3$ \\
\hline
\end{tabular}




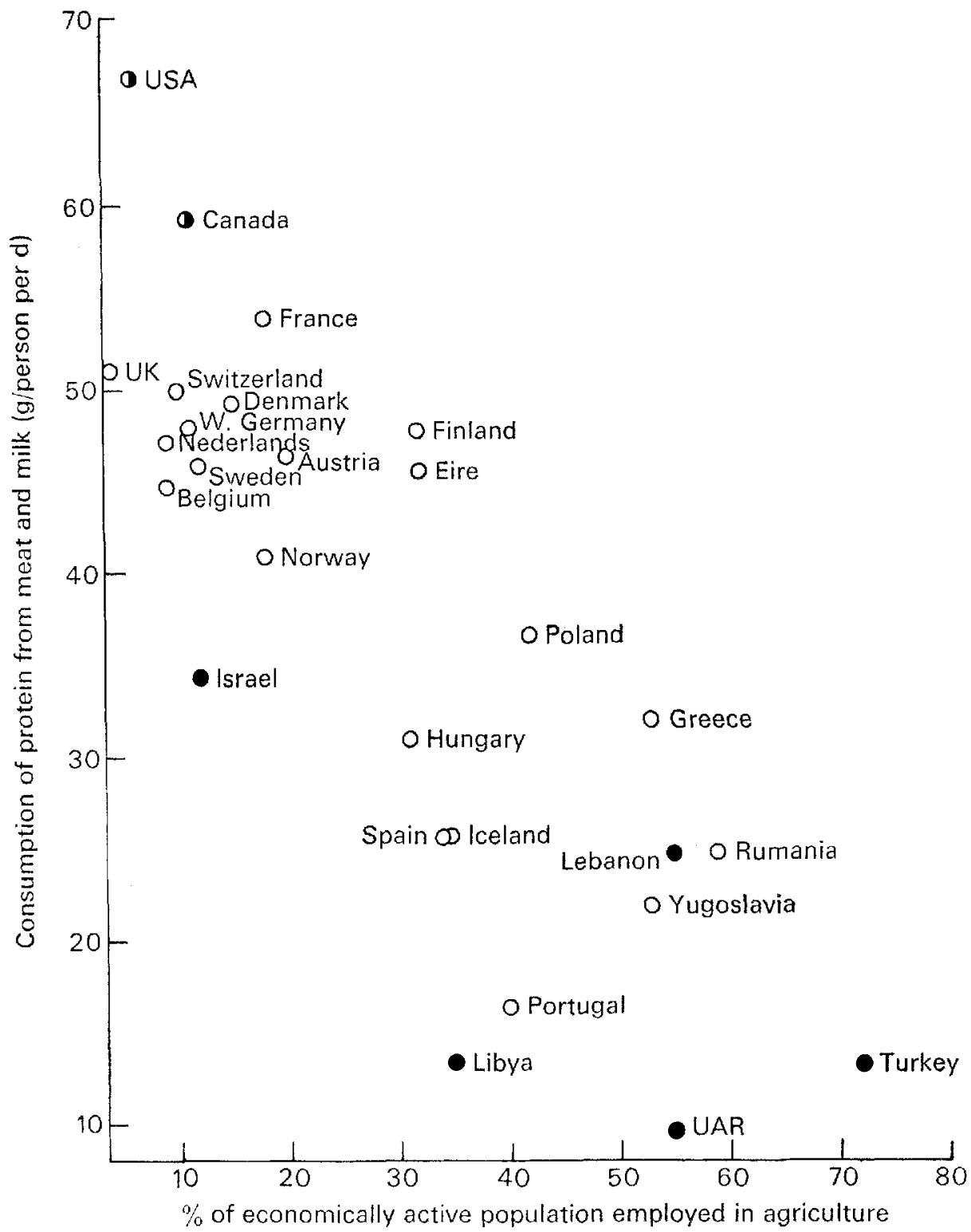

Fig. 1. Consumption of protein from meat and milk in relation to the proportion of economically active population employed in agriculture (calculated from data in FAO, 1969a). ( North America; $O$, Europe; Middle East.

Fig. 2, derived from the same data as Fig. I, shows the relationship between daily meat supplies and the wealth of the same countries. Again, a decline in consumption occurs with increasing proportion of agricultural workers. The spread of points is greater than for meat and milk together, possibly because Scandinavian countries have a propensity for consuming very large amounts of milk and slightly less meat than a general expectation would suppose. Even so, there is some evidence 


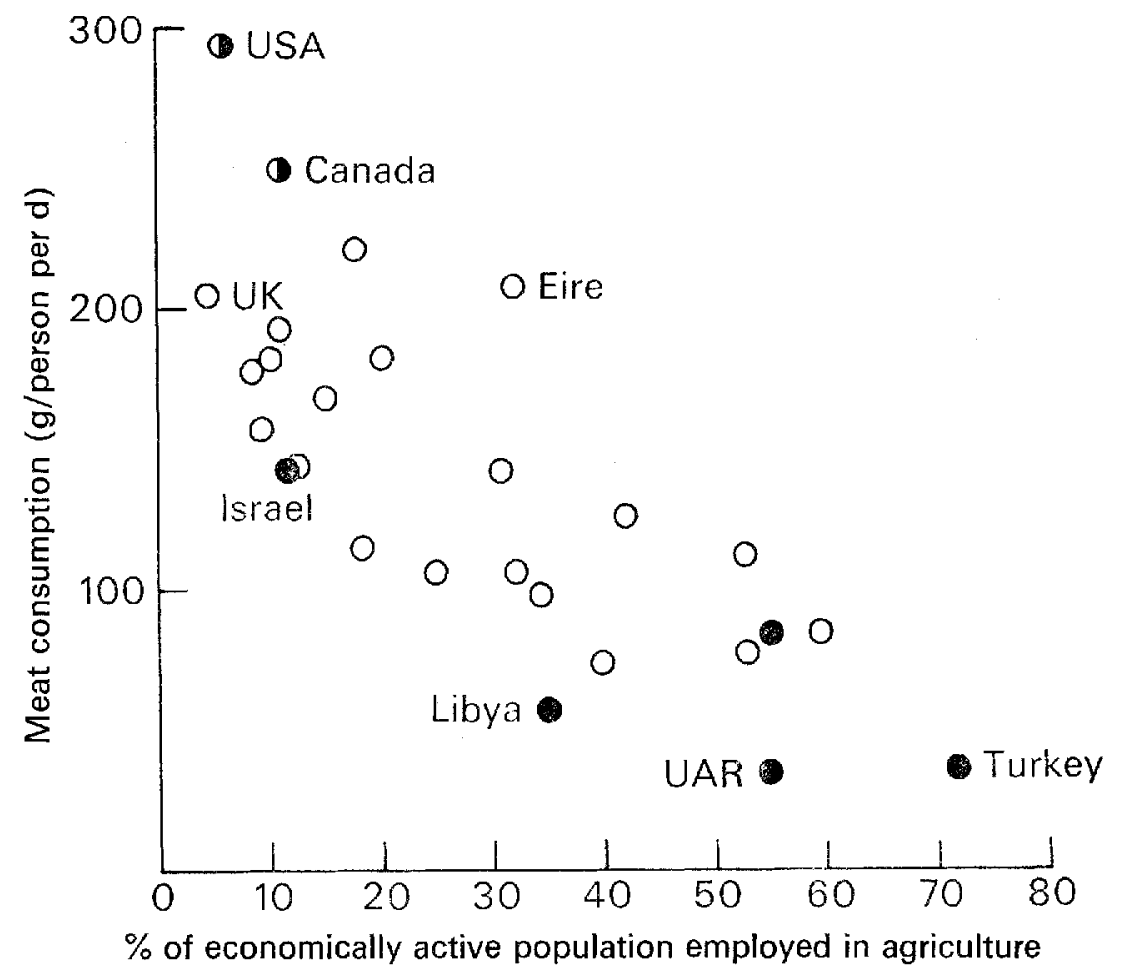

Fig. 2. Consumption of meat in relation to the proportion of economically active population employed in agriculture (calculated from data in FAO, 1969a). 1 , North America; O, Europe; 0 , Middle East.

that the relationship is steeper initially, that is meat consumption increases more rapidly with heavy industrialization than in the early stages. This is supported by the fact that milk consumption varies very little about a mean of $650 \mathrm{~g} / \mathrm{d}$ for countries with less than $20 \%$ of the population engaged in agriculture.

These computations suggest that increases in wealth are associated with an increase in the demand for milk and meat and that the wealth associated with a considerable degree of industrialization is associated with an enhanced demand for meat. Conversely, as shown in Fig. 3, when meat consumption increases, cereal consumption falls. These data represent absolute changes in the quantities of cereals and carcass meat consumed per capita over the period $1948-52$ to 1967 . Again, Scandinavian countries are anomalous probably for the reason already given. As with the passage of time countries improve their economies, so, less bread, grain, rice and other cereal staples are consumed by their peoples and meat and, to a lesser extent, milk are taken in preference.

A closer examination of food consumption in one of the wealthiest countries of the world, the USA, shows the changes in food preference more direct and this is given in Table 3. Over a 20-year period the mean consumption of meat from ruminant animals increased by $40 \%$, the consumption of non-ruminant meat by $26 \%$ while the consumption of milk fell by $12 \%$. The increase in ruminant meat 


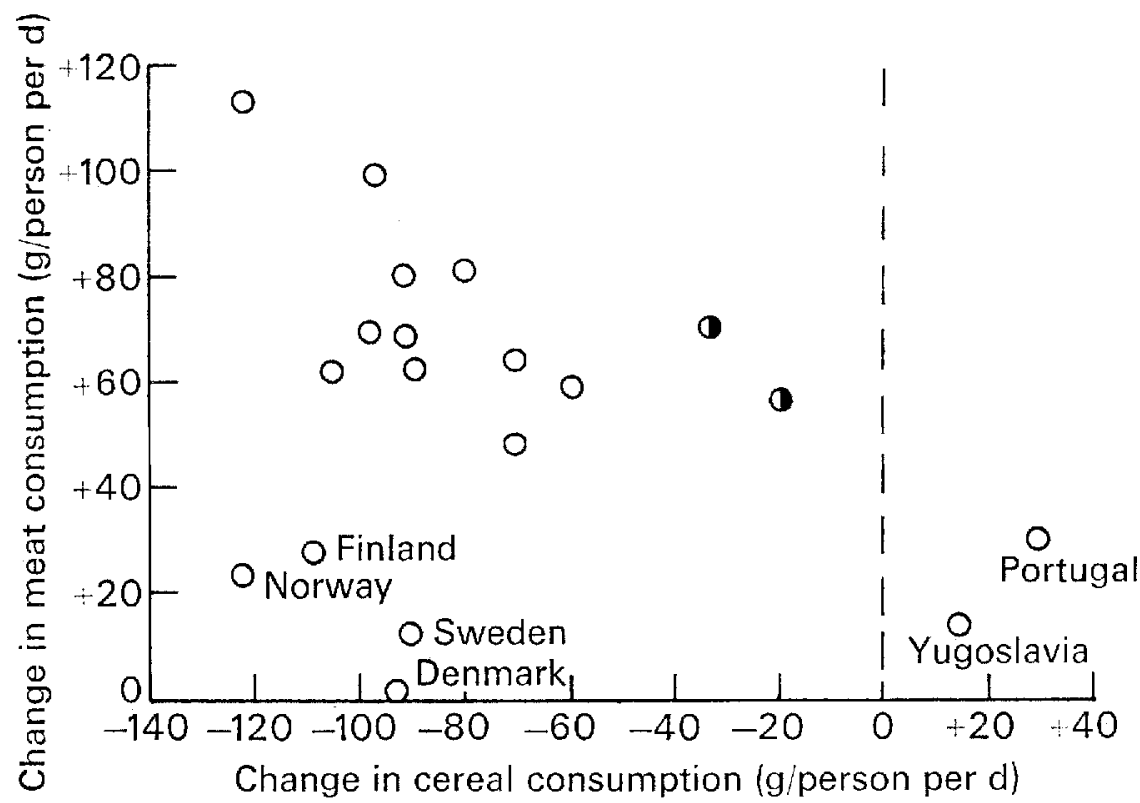

Fig. 3. Change in consumption of meat in relation to change in consumption of cereal (calculated from data in FAO, 1969a). (1, North America; O, Europe.

was accounted for by an increase of $66 \%$ in beef consumption, for lamb and mutton, consumption declined by $24 \%$. The increase in non-ruminant meat was accounted for by a $109 \%$ increase in poultry meat consumption, for pork and bacon, consumption fell by $3 \%$. These figures show a distinct preference for meat from cattle and poultry and a discrimination against sheep meat and pork. Obviously price is a real factor but there is in addition a demand for beef which is in part independent of price.

Table 3. Changes in USA food consumption per capita in 20 years $194^{8-68 *}$ (Goldberg, 1969)

\begin{tabular}{|c|c|c|c|}
\hline & $\begin{array}{c}1948 \\
(\mathrm{~kg} / \text { annum) }\end{array}$ & $\begin{array}{c}\mathrm{I} 968 \\
\text { (kg/annum) }\end{array}$ & $\begin{array}{c}\text { Change } \\
(\%)\end{array}$ \\
\hline Animal products & & & \\
\hline Ruminants* & 29 & 39 & +40 \\
\hline Dairy products & 156 & $\mathrm{I}_{3} 8$ & -12 \\
\hline Non-ruminants $\uparrow\{$ Meat & 39 & 48 & +26 \\
\hline Plant products & 22 & 19 & - I 5 \\
\hline Cereals, flour, sugar, pulses $\ddagger$ & 133 & 123 & -8 \\
\hline Fruits & 78 & 58 & -29 \\
\hline Vegetables & 103 & 89 & -13 \\
\hline Potatoes and sweet potatoes & $5 \mathrm{I}$ & $4^{8}$ & -8 \\
\hline
\end{tabular}

*Beef consumption increased by $63 \%$, lamb and mutton consumption declined by $24 \%$. + Pork consumption decreased by $3 \%$, poultry meat consumption increased by 109\%.

†Sugar consumption increased by $7 \%$, flour and cereal consumption decreased by $18 \%$. 
A similar situation, though not so extreme, is currently occurring in the UK; milk consumption is static or declining, and carcass and poultry-meat consumption is increasing. A comment in the National Food Survey (Ministry of Agriculture, Fisheries and Food: National Food Survey Committee, 1969) is revealing in this respect. Following upon an analysis of the own-price elasticity of demand for meat and the income elasticity of demand for meat, it is stated 'over the period I $962-7$ it therefore appears from this analysis, tenuous though it may be, that there might have been some slight strengthening in household demand for meat over and above that due to changes in prices and in incomes'. That this reflects differences in social attitudes and social class is illustrated in Table 4 where the mean consumption

Table 4. Consumption of certain foods per person per week in social class $\mathrm{AI}_{\mathrm{I}}$ and $\mathrm{D}_{2}$ (Ministry of Agriculture, Fisheries and Food: National Food Survey Committee, 1969)

\begin{tabular}{|c|c|c|c|}
\hline & $\begin{array}{l}\text { Social class } \\
\qquad A_{x}\end{array}$ & $\begin{array}{c}\text { Social class } \\
\text { D } 2\end{array}$ & $\begin{array}{c}\text { Increase } \\
\mathrm{A}_{1}: \mathrm{D}_{2}(\%)\end{array}$ \\
\hline Milk and cream (pint or equivalent pint) & $5 \cdot 87$ & $5 \cdot 22$ & +12 \\
\hline Beef and veal $(o z)$ & 14.22 & $8 \cdot 14$ & +74 \\
\hline Mutton and lamb $(o z)$ & $9 \cdot 08$ & $8 \cdot 54$ & 6 \\
\hline Pork, bacon and ham (oz) & 10.27 & $6 \cdot 25$ & +64 \\
\hline Poultry (oz) & $6 \cdot 17$ & $3.5 \mathrm{I}$ & +76 \\
\hline Other meat* (oz) & r r $\cdot 43$ & I $2 \cdot 3 \mathrm{I}$ & -7 \\
\hline Total meat (oz) & $51 \cdot 17$ & $36 \cdot 27$ & $+4 \mathbf{I}$ \\
\hline
\end{tabular}

*Rabbit, game, corned meat, canned meat, sausages, etc.

per week for social class $\mathrm{AI}$ and social class $\mathrm{D} 2$ are compared. The original data in the pleasant archaic units of ounces (presumably avoirdupois) per week and pint equivalents per week have not been converted. Table 4 shows that more well-to-do people increase their consumption of beef and pork, discriminate against 'other meat' (defined in the footnote), and increase their consumption of milk and mutton and lamb very little.

Table 5 summarizes the proportion of carcass meat produced in different areas

Table 5. The percentage of the indigenous production of carcass meat accounted for by meat from ruminants and pigs in $1948-52$ and in 1967 (FAO, 1969a)

\begin{tabular}{|c|c|c|c|c|}
\hline & & $\begin{array}{l}\text { Beef, veal } \\
\text { and buffalo }\end{array}$ & $\begin{array}{l}\text { Mutton, lamb } \\
\text { and goat }\end{array}$ & Pig \\
\hline \multirow[t]{2}{*}{ Europe } & I $948-52$ & $42 \cdot 4$ & $6 \cdot 6$ & סיזי 5 \\
\hline & I967 & $4 I \cdot 9$ & $5 \cdot 4$ & $52 \cdot 7$ \\
\hline \multirow{2}{*}{ North America } & $1948-52$ & $48 \cdot 5$ & $2 \cdot 7$ & $48 \cdot 7$ \\
\hline & 1967 & $6 \mathrm{I} \cdot 3$ & $\mathrm{r} \cdot 8$ & $36 \cdot 8$ \\
\hline \multirow[t]{2}{*}{ Latin America } & $1948-52$ & $78 \cdot 4$ & $6 \cdot 8$ & 14.8 \\
\hline & 1967 & $76 \cdot 3$ & 5.5 & $17 \cdot 9$ \\
\hline \multirow{2}{*}{ Near East } & $1948-52$ & $45^{\circ} 8$ & $53 * 4$ & 0.8 \\
\hline & 1967 & $48 \cdot \mathrm{I}$ & 50.9 & 0.9 \\
\hline \multirow[t]{2}{*}{ Far East } & $1948-52$ & $45^{\circ} 9$ & $23 \cdot 2$ & 30.9 \\
\hline & 1967 & $32 \cdot 7$ & $\pm 5^{\prime 2}$ & $52 \circ$ \\
\hline \multirow[t]{2}{*}{ Africa } & $1948-52$ & $69 \cdot 2$ & $23 \cdot 1$ & $7 \cdot 6$ \\
\hline & 1967 & $69 \cdot 2$ & 24.4 & $6 \cdot 4$ \\
\hline \multirow{2}{*}{ Oceania } & $1948-52$ & $5 \mathrm{I} \cdot \mathrm{I}$ & 40.9 & 8.0 \\
\hline & 1967 & 46.9 & $45 \cdot 8$ & $7 \cdot 3$ \\
\hline
\end{tabular}


of the world in $1948-52$ and for the last year for which FAO statistics are available. This indicates that the North American situation may well be unique for in no other region has a similar change in emphasis on beef production taken place; indeed, in the Far East a considerable increase in pig-meat production has taken place. North America is, however, the most wealthy of the regions listed.

Given the premises firstly that the food demands of people in the less wellendowed countries will, as they aspire to and achieve greater wealth, tend to accord with what is at present the demand in more industrialized societies, secondly that recent patterns of change in demand in the USA will be repeated in other Western societies, and thirdly that differences in food consumption in different social classes are indicative of a trend to be repeated as the affluence of industrial populations grows, then certain conclusions can be drawn with respect to the future demands to be made of ruminant animals. Milk production can be expected to increase until in societies aspiring to Western standards it averages $600 \mathrm{~g} /$ person per d, meat production will increase to provide $200 \mathrm{~g} /$ person per $\mathrm{d}$. The proportion of this meat derived from cattle and poultry will increase, that from sheep and goats, and to a lesser extent, that from pigs, will decline. Not all societies necessarily so aspire. Traditional food preferences, particularly in Asia and the Far East may well entail different emphases, as wealth increases, on eggs, poultry meat, fish and other foods rather than on milk and carcass meat. Similarly these predictions, even when applied to 'Western' societies, are based on current technologies and it is possible that the products of new food technologies, despite some consumer resistance to them (Galliver, 1969), will in the next 20 years reduce their magnitude. The process, however, is not likely to render them nugatory. Even without considering other items of diet, these amounts of milk and meat together provide more protein than the minimal requirement of man (Hegstedt, 1964). They are in effect estimates of 'dietary aspirations' rather than of strict nutritional need. In this respect Table 6 shows the results of a recent French survey. French people, if their financial state

Table 6. Foods, the consumption of which French people would like to increase if their financial status were improved (\% of total replies) (Claudian \& Serville, I968)

$\begin{array}{lcccc} & \text { All replies } & \begin{array}{c}\text { Professional } \\ \text { people }\end{array} & \begin{array}{c}\text { Skilled } \\ \text { workers }\end{array} & \text { Rural workers } \\ \text { Meat } & 53 \cdot 3 & 3 \mathrm{I} \cdot 7 & 7 \mathrm{r} \cdot 7 & 46 \cdot 8 \\ \text { Processed foods } & \mathrm{I} 2 \cdot 9 & 3 \cdot 7 & 2 \cdot 6 & 4 \cdot \mathrm{I} \\ \text { Fruit } & 7 \cdot 4 & 9 \cdot 8 & 2 \cdot 6 & 18 \cdot 4 \\ \text { Vegetables } & 6 \cdot 9 & - & 12 \cdot 8 & 12 \cdot 3 \\ \text { Fish, shell-fish } & 4 \cdot 9 & 14 \cdot 6 & - & 3 \cdot 0 \\ \text { Other foods } & 14 \cdot 6 & 12 \cdot 2 & 10 \cdot 3 & 16 \cdot 4 \\ \quad \text { Total } & 100 \cdot 0 & 100 \cdot 0 & 100 \cdot 0 & 100 \cdot 0\end{array}$

improved, wished to increase their meat consumption more than that of other foods (Claudian \& Serville, 1968). A further factual survey in the same study indicated a greater proportional consumption of beef by professional people than by manual workers, as in the British survey, and in a concurrent opinion survey a 
general wish to increase its consumption relative to that of other meats. This was stronger in the lower socio-economic groups.

If those peoples of the world currently aspiring to Western standards of living could instantaneously achieve them, then our current world production of milk needs to increase by $50 \%$ and the production of ruminant meat needs to double. World population, however, is, as we are constantly reminded, far from static and Western standards of living appear to be highly infectious. It seems probable that by $\mathrm{AD} 2000$ we need to cater for a potential demand equivalent to a doubling of current world milk production and a quadrupling of current world-meat production. It is of interest that the long-term estimates of dietary aspiration agree broadly with estimates based on needs for milk nutrients (UNO, 1968) but are very considerably greater than nutritionally-based estimates of need for meat, particularly ruminant meat.

Some inaccuracies are present in both approaches because of uncertainties about population growth. I do not think that the estimates made by FAO are necessarily correct; they are too high. It is highly unlikely that growth of the world population is exponential with a compound interest rate of $I \cdot 7$ to $2 \cdot 2$ (USA: Govern-

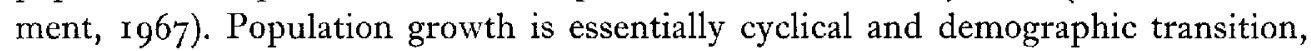
though not completely explained, still reflects what happens to countries which undergo development. An extension of the principle explains the increases still occurring in developed ones (Spengler \& Duncan, I956). Even so, these uncertainties about population, though real, are no greater than the uncertainties of predicting the aspirations of people with respect to the type of food they want to eat, and the estimates that milk production should be doubled and ruminant meat production quadrupled by the end of the century are probably realistic.

The questions then arise whether such targets could be achieved and whether in fact we have sufficient natural resources which we can divert from direct cropping for human food to the indirect process of producing the more acceptable and desired products, meat and milk. These questions raise problems concerning the competition of animals with man for the primary produce of land, and some calculations based on ideas of crop surplus conversion suggest that even less ambitious targets than those given above are beyond our present technical knowledge.

An example is a calculation by Reid (I970). Reid took FAO estimates of population growth, realistic estimates of the energy needs of man, and computed the world requirements of cereals and vegetable foods for the direct feeding of man. With an assumed $\mathrm{I} \%$ per annum growth of primary plant production a surplus was found, and this was taken as available to feed animals. The feed was apportioned in the order: pigs, laying hens, broilers, milking ruminants, meat ruminants, and it was found that insufficient cereal equivalent was available to meet his estimates of population needs for meat, needs, incidentally, considerably lower than those developed here. The ruminants' maintenance and reproductive needs were assumed to be met from roughages.

Besides the basic assumptions about population growth, about the growth rate of primary plant production and about priorities in apportioning feed, Reid also 
assumes implicitly that animals are supported by foods and food by-products surplus to man's needs. This is not necessarily so, for surplus human food production implies surplus land resources and these land resources could well be used to grow crops better fitted to maximize ruminant meat and milk production (Blaxter, 1970). In addition, Reid does not take into account the contribution made by lands which are not fitted to arable cropping.

On the first point, direct experimentation (K. L. Blaxter, F. Wainman, P. Dewey, J. Davidson, H. Denerley \& J. B. Gunn, I970, unpublished) supports practical experience to show that intensive utilization of grassland in northern temperate regions can result in an output of beef per ha which is 2.5 times that achieved by a cropping policy with coarse grains and cereals. Calculations from these data show (Blaxter, 1969) that per unit area of land, beef production, energetically the least efficient of our agricultural production processes, results in as much muscle protein when cropping is designed to provide feed specifically for ruminants as does a pig production system in which the cropping is with cereal grains and pulses which could be used, after refining, by man. On the same basis the production of milk protein per unit area is very much greater than the production of either pig meat or beef.

On the second point it has to be remembered that arable and planted crops account for a world acreage only half that occupied by natural grasslands and only a third that of the world's natural forests. The former and part of the latter can only be converted into food for man by grazing herbivores, the most important of which are the ruminants. Their importance in the world meat economy is very considerable indeed when it is remembered that Argentina alone produces about one-tenth of the world's meat. On this basis, Reid's predictions of disaster and a failure of secondary animal production to keep pace with population growth and nutrient need seem unduly pessimistic. They stem from the view that animals generally are competitors for human food. Ruminants are not to be regarded in this way. Rather they are the commensals of man.

Ruminants can utilize cellulose, man cannot. Ruminants can, through the activities of their rumen flora, convert non-protein nitrogen-containing materials to useful protein. Ruminants can utilize the waste products of human food production whether from the farm or from the processing plant or factory. Ruminants can obtain food from areas not accessible to cultivation, and ruminants produce foods which are in very high demand. In this respect, while the United Nations Committee report on the action to be taken to avert the impending protein crisis (UNO, I968) discussed at length new sources of protein, unfamiliar ones and possibly unacceptable ones, its main recommendation was that existing agricultural technologies should be expanded. This is a realistic view.

Finally, on the question of whether agricultural technology can ensure an expansion of the magnitude envisaged, it is relevant to note that, in the USA, acreage controls on production currently mean that one-quarter of the land is out of production (Goldberg, 1969). The Mansholt plan for the European Economic Community calls for the taking out of production of an area which is about $12 \%$ of the total 
arable area of the six member countries. In Sweden, current plans are to take r 000000 ha, approaching $30 \%$ of the arable acreage, out of production. All these changes suggest very strongly that primary plant production in the world is well able to meet man's needs and that land resources are available even in highly industrialized countries for further augmentation of output. I share the view expressed by Dr McMeekan in the Hammond Memorial Lecture (McMeekan, 1969) that the agricultural and animal production resources of the world are perfectly adequate to cope with foreseeable demands.

\section{REFERENCES}

Blaxter, K. L. (1969). Proceedings Second World Conference on Animal Production p. 3r. St. Paul, Minnesota: American Dairy Science Association.

Blaxter, K. L. (1970). Chemy Ind. (In the Press.)

Byerly, 'T. C. (1966). F. Anim. Sci. 25, 522.

Claudian, J. \& Serville, Y. (1968). Cah. Nutr. Diét. 3, 29.

FAO (Ig6ga). Prod. Yb. FAO r968, Vol. 22.

FAO (1969b). St, Fd Agric. 1969.

Galliver, G. B. (1969). Proc. Nutr. Soc. 28, 97.

Goldberg, R. A. (1969). \%. Fmrs' Club October, p. 8I.

Fegstedt, D. M. (1964). In Mammalian Protein Metabolism Vol. 2, p. 135 [H. N. Munro and J. B. Allison, editors]. London: Academic Press.

McMeekan, C. P. (1969). Anim. Prod, Ir, 271.

Ministry of Agriculture, Fisheries and Food: National Food Survey Committee (1969). Household Food Consumption and Expenditure, 1967 with a Supplement giving Preliminary Estimates for 1968. London: H.M. Stationery Office.

Millikan, M. F. (1967). Science, N.Y. 158, 1560.

Phillips, R. W. (1969). Proceedings Second World Conference on Animal Production p. I5. St. Paul, Minnesota: American Dairy Science Association.

Reid, J. T. (1970). In Physiology of Digestion and Metabolism in the Ruminant p. I. [A. T. Phillipson, editor]. Newcastle upon Tyne: Oriel Press.

Spengler, J. J. \& Duncan, O. D. (1956). Population Theory and Policy. Glencoe, Illinois: 'The Free Press.

UNO (1968). International Action to Avert the Impending Protein Crisis. New York: United Nations Organization.

USA: Government (1967). The World Food Problem Vol. 2. Report of the President's Science Advisory Committee. Washington, D.C.: US Government Printing Office.

\section{The role of poultry}

\section{By W. Bolton, Agricultural Research Council Poultry Research Centre, West Mains Road, Edinburgh $\mathrm{EH}_{9} 3 \mathrm{FS}$}

Any paper which attempts to forecast the future is bound to be speculative and the author must be prepared to find that all his prophecies have been proved wrong. The best one can hope to do is to look at developments in the immediate past and use these as a factual basis for crystal-ball gazing.

The species of poultry used for the production of human food are the fowl, turkey, 